\title{
Algunos problemas en torno al obispo Euzoio de Antioquía
}

\author{
GonZALO FernánDEZ
}

\begin{abstract}
RESUMEN ABSTRACT
Este artículo estudia algunas cuestiones relativas al obispo Euzoio This article deals with some questions concerning Bishop Euzoius of Antioch. de Antioquia. Las fuentes son Atanasio de Alejandría, Sócrates, Sozomeno, Filostorgio, Teodoreto de Ciro, el Código Teodosiano, Epifanio de Salamina y Ammiano Marcelino. The sources are Athanasius of Alexandria, Socrates, Sozomen, Philostorgius, Theodoret of Cyr, the Theodosian Code, Epiphanius of Salamis and Ammianus Marcellinus.
\end{abstract}

Euzoio es un diácono de Alejandría y discípulo de Arrio. Hacia 320 ambos son condenados por el sínodo que el obispo Alejandro reúne en aquella urbe (Sócrates, Hist. Eccl. I, 6). Constantino I "el Grande" destierra a Euzoio a lliria tras la asamblea nicena de 325. Es rehabilitado por el pequeño concilio provincial de obispos bitinios que acaece en la propia ciudad de Nicea en el otoño de 327 en cumplimiento del canon 5 del sínodo mismo de 325 y habitualmente confundido con el segundo sínodo general de Nicea o al menos con la segunda sesión solemne del concilio niceno de 325. Nuestro personaje sólo vuelve a ser admitido a la plena comunión eclesiástica en 335 con el traslado a Jerusalén de los sinodales de Tiro para participar en la consagración de la Basílica y el "Martyrion» del Santo Sepulcro.

* Universidad de Valencia. 
Su figura plantea algunos problemas al difuminarse su rastro entre la antedicha rehabilitación por los conciliares tirios en la Ciudad Santa y su presencia en el concilio de Seleucia de 359. Filostorgio (Hist. Eccl. V, 5), Sócrates (Hist. Eccl. II, 44), Sozomeno (Hist. Eccl. IV, 28) y Teodoreto de Ciro (Hist. Eccl. II, 27) dicen que Euzoio es consagrado presbítero por «el obispo arriano de Antioquía" aunque no indican el nombre de ese pastor. Ello señala que en algún momento anterior Euzoio perdió su condición presbiterial. Epifanio de Salamina (Panar. Haer. 73, 27) afirma la pertenencia de Euzoio en los ínicios del concilio de Seleucia de 359 al grupo de arrianos en sentido estricto donde se encuentran también Jorge de Alejandría y Eudoxio de Antioquía. Epifanio (loc. cit.) añade a continuación que Euzoio, convertido ya en obispo de Antioquía, protege a los anomeos de la «Perla del Orontes». Sócrates (Hist. Eccl. II, 45) y Sozomeno (Hist. Eccl. IV, 29) aluden a la reunión de un sínodo en Antioquía, por orden del obispo Euzoio y en presencia de Constancio II, cuyos partícipes proclaman al Hijo disimilar al Padre no sólo en virtud de la sustancia sino también por la voluntad. Igualmente aquellos conciliares antioquenos definen la creación del "Logos» de la nada. Atanasio de Alejandría (De Syn. 31) no menciona la existencia de ese sínodo antioqueno pero indica que en la Antioquía del obispo Euzoio se registra un renacimiento de la propaganda arriana radical en detrimento de las doctrinas homeas y beneficiando las tesis anomeas.

Ante este panorama de fuentes propongo la siguiente reconstrucción de los acontecimientos. Euzoio se habría inclinado al anomeísmo en época del obispo Leoncio de Antioquía (344-357). Leoncio condena y depone del diaconado a Aecio por presiones populares y ante las tendencias de éste último al anomeismo. Ello trae como consecuencia que Leoncio despoje asimismo del presbiteriado a Euzoio quien comparte con Aecio sus radicales tendencias teológicas. Sabemos, además, por Filostorgio (Hist. Eccl. III, 15) que Aecio mantiene contactos con los sobrevivientes de la escuela luciánica, con la que Arrio se identificaba, y Euzoio es uno de los últimos discípulos directos de Arrio. Leoncio muere y su sucesor Eodoxio, obispo de Antioquía de 357 a 360, vuelve a consagrar presbitero a Euzoio por la política inicial de Eudoxio de apoyar a los sectores más extremistqas del arrianismo. Por tanto Eudoxio es el innominado "obispo arriano de Antioquía" aludido por las fuentes que recogen la segunda ordenación sacerdotal de Euzoio (Filostorgio, Hist. Eccl. V, 5, Sócrates, Hist. Eccl. II, 44, Sozomeno, Hist. Eccl. IV, 28 y Teodoreto de Ciro, Hist. Eccl. II, 27).

Epifanio de Salamina (Panar. Haer. 73,27 ) dice que en las sesiones inaugurales del concilio de Seleucia de 359 Euzoio, presbítero a la sazón, forma parte del grupo eclesiástico capitaneado por su protector Eudoxio, 
aún obispo de Antioquía. En enero de 360 Eudoxio logra el traslado de Antioquía a Constantinopla. A principios de 361 Eudoxio consigue la ordenación de Euzoio como obispo de Antioquía tras la deposición y condena al exilio de Melecio ${ }^{1}$. En su gobierno episcopal Euzoio no ataca frontalmente el credo defendido por la facción acaciana pero intenta convencer a Constancio II de la oportunidad de volver al anomeísmo en el sínodo antiqueno de 361 (Sócrates, Hist. Eccl. II, 45 y Sozomeno, Hist. Eccl. IV, 29).

Este postrer concilio ha de celebrarse antes del inicio de la cuaresma de aquel año en cumplimiento del quinto canon del sínodo de 325 que ordenaba la celebración de dos sínodos anuales en cada provincia eclesiástica: uno antes del principio del tiempo cuaresmal y otro en otoño. Esta cronología coincide con que el 14 de febrero de 361 Constancio II firme en Antioquía una medida alusiva a las inmunidades eclesiásticas (Cod. Theod. XVI, 2 16). No sabemos como el emperador acepta la sugerencia de Euzoio porque la puesta en marcha de una campaña contra los persas en mayo de 361 (Ammiano Marcelino, Hist. XXI, 7, 7) y los problemas que tiene con el césar Juliano a partir de agosto del mismo año impiden que adopte una decisión ${ }^{2}$. En el estado actual de nuestros conocimientos sólo puede afirmarse que Constancio II no desdeñaría "a priori» la proposición de Euzoio por su elevada estima hacia el obispo. Ese afecto imperial se hará visible muy poco tiempo después, concretamente a principios de noviembre de 361, cuando Euzoio de Antioquía derrame las aguas bautismales sobre Constancio II en su lecho de muerte (Atanasio, De syn. 31 y Filostorgio, Hist. Eccl. VI, 5).

La fecha de la deposición episcopal y destierro de Melecio de Antioquía en M. SimONEITI, La crisi ariana nel IV secolo, Roma, 1975, pág. $345, n .{ }^{\circ} 82$.

2 Las dataciones de los sucesos de 361 en O. SEECK, Regesten der Kaiser und Päpste für Jahre 311 bis 476 n. Chr., Francfort del Meno, 1964 (reimpr.), pág. 208. A la ordenación de Euzoio como obispo de Antioquia se refieren TEODORO DE Ciro, Hist. Eccl. II, 31, SOCRATES, Hist. Eccl. II, 44, SOZOMENo, Hist. EcCl. IV, 28 y Filostorgio, Hist. Eccl. V, 5. 


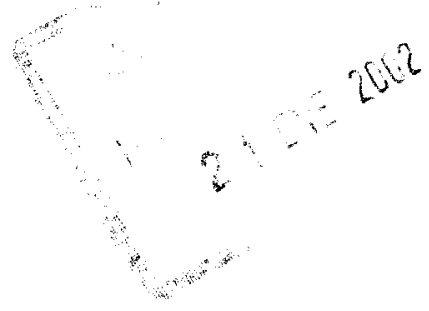

